\title{
Optimization of Newly Opened Rice Fields on Tidal Swamp Through Superior Rice Varieties in Bulungan District
}

\section{Muhamad Hidayanto and Yossita Fiana}

Assessment Institute for Agricultural Technology of East Kalimantan, Samarinda, East Kalimantan, Indonesia 75119

\section{ARTICLE INFO}

\section{Received}

23 March 2020

\section{Revised}

8 March 2021

\section{Accepted for Publication \\ 18 March 2021}

\section{Published}

8 October 2021

doi: 10.29244/j.agromet.35.2.89-97

\section{Correspondence:}

Muhamad Hidayanto

Assessment Institute for Agricultural

Technology of East Kalimantan,

Samarinda, East Kalimantan,

Indonesia 75119

Email:mhidayanto@yahoo.com

This is an open-access article distributed under the CC BY License. (C) 2021 The Authors. Agromet.

\begin{abstract}
A B S T R A C T
Indonesian swamp has a high potency to provide areas for agricultural expansion, which means to raise food security. To optimize its utilization, government has developed new rice fields in the tidal swamp. This research was carried out in a new rice field from the tidal swamp in Bulungan District. The research aimed to optimize the new rice fields by implementing superior rice varieties (NSV). The study used a randomized block design (RBD) with three replicates. Benefit Cost Ratio (BCR) analysis was performed to determine the feasibility of rice farming in the new field. The NSV consisted of six varieties of rice, namely Inpara-1, Inpara-2, Inpara-3, Inpara-4, Inpara-5, and a local variety. The planting pattern implemented was jajar legowo (jarwo) 2:1, and seedlings were planted three stems per clump at the age of 20-25 days. Each planting treatment was given the same dose of limestone and fertilizer, namely dolomite $1,000 \mathrm{~kg} \mathrm{ha}^{-1}$, NPK fertilizer $250 \mathrm{~kg} \mathrm{ha}^{-1}$, and Urea $100 \mathrm{~kg} \mathrm{ha}^{-1}$. The results showed that all varieties were able to adapt tidal swamp condition, and Inpara varieties productivity was higher than that of local variety. The productivity of superior varieties rice in a newly opened rice reached $2.6-5.75$ tons milled dry grain ha ${ }^{-1}$. The findings also revealed that superior rice varieties have $B C R>1$, while the local variety had $B C R<1$. The productivity of Inpara- 1 and Inpara- 2 was the highest compared to other varieties and was also feasible to be cultivated on newly opened rice fields in Bulungan District.
\end{abstract}

\section{KEYWORDS}

benefit-cost ratio, Duncan Multiple Range Test, plant growth analysis, rice productivity, soil properties

\section{INTRODUCTION}

Indonesian food demand, especially rice, continues to rise annually in response to population growth. However, rice fields in some regions gradually decreased since it was converted to non-agricultural land, such as built-up area (Pravitasari et al., 2019), and tourist accommodation (Lanya et al., 2017). In fact, rice itself has a strategic function as the main staple for most Indonesians (Resiani and Sunanjaya, 2020; Widiatmaka et al., 2016; Wijaya, 2019). To maintain the sustainability of rice supply, productive rice fields need to be preserved, hence it would not be a threat to food security (Sugiarto et al., 2017). Therefore, since 2015, the Ministry of Agriculture, Government of Indonesia has implemented a program related to development of new rice fields. By area expansion, it is expected that national rice yield will increase.

Newly opened rice fields could be developed from dryland or wetlands, such as in swamps. However, converting swamp to rice fields will trigger many adverse impacts in terms of their biophysical, socioeconomic, and institutional aspect (Surahman et al., 2018). Several problems will raise such as sea-water runoff (Weissman and Tully, 2020), high amount of $\mathrm{Al}^{3+}$, 
$\mathrm{Fe}^{2+}$, and $\mathrm{H}^{+}$causing low concentration of $\mathrm{Ca}, \mathrm{Mg}, \mathrm{K}$, and Mo (Dawid and Hailu, 2017); the leaching of $\mathrm{Ca}^{2+}$, $\mathrm{Mg}^{2+}$, and $\mathrm{K}^{+}$resulting in acid soil; the low amount of $\mathrm{P}$, $\mathrm{Cu}, \mathrm{Zn}$ and $\mathrm{B}$ leading to low soil fertility (Mugo et al., 2020); frequent pest and disease attacks; lack of superior seeds utilization; ferro toxicity (Suciantini et al., 2008); climate factors (Suciantini et al., 2020), and only once a year rice planting time (Maruapey et al., 2020; Paiman et al., 2020). By managing the constraints, the newly opened rice fields in the tidal swamp will support the provision of rice, for both regional and national demand.

To overcome the low fertility rates of newly opened rice fields, an optimization to increase land productivity is required by introducing location-specific technological innovations (Gatzweiler and Von Braun, 2016; Gusmiatun, 2020). Optimization of new rice fields in the tidal swamp can be performed through various methods, such as a location-specific land arrangement, water system management, amelioration, site-specific fertilization, and the use of superior varieties (Rumanti et al., 2018). Rice superior variety is a component of technology aimed to increase the productivity of newly opened rice fields (Alfayanti et al., 2020; Aristya et al., 2021). This research aimed to analyze the optimization procedure of the newly opened rice fields from the tidal swamp by using the new adaptive superior varieties (NSV), which correspond to site-specific conditions.

\section{RESEARCH METHODS}

This research was conducted in October 2018January 2019 in a newly opened rice field area located in Transmigration Settlement Unit (UPT) Sepunggur, Tanjung Palas District, Bulungan District (Figure 1). Samples of composite soils were collected from five locations (Table 1). Several information extracted from each soil sample included $\mathrm{pH}$, organic matter, $\mathrm{P}_{2} \mathrm{O}_{5}$ and $\mathrm{K}_{2} \mathrm{O}$ content, $\mathrm{P}$ content, $\mathrm{Al}$ content, microelement content, exchangeable bases ( $\mathrm{Ca}, \mathrm{Mg}, \mathrm{K}$, and $\mathrm{Na})$, and Cation Exchange Capacity (CEC).

Table 1. Locations of soil sampling.

\begin{tabular}{cccc}
\hline Loc. & Latitude & Longitude & $\begin{array}{c}\text { Elevation } \\
\text { (m.asl) }\end{array}$ \\
\hline 1 & $2^{\circ} 50^{\prime} 25^{\prime \prime}$ & $117^{\circ} 30^{\prime} 15^{\prime \prime}$ & 4.7 \\
\hline 2 & $2^{\circ} 50^{\prime} 29^{\prime \prime}$ & $117^{\circ} 30^{\prime} 17^{\prime \prime}$ & 7.1 \\
\hline 3 & $2^{\circ} 50^{\prime} 29^{\prime \prime}$ & $117^{\circ} 30^{\prime} 08^{\prime \prime}$ & 6.1 \\
\hline 4 & $2^{\circ} 51^{\prime} 59^{\prime \prime}$ & $117^{\circ} 28^{\prime} 11^{\prime \prime}$ & 53.1 \\
\hline 5 & $2^{\circ} 52^{\prime} 00^{\prime \prime}$ & $117^{\circ} 28^{\prime} 17^{\prime \prime}$ & 56.1 \\
\hline
\end{tabular}

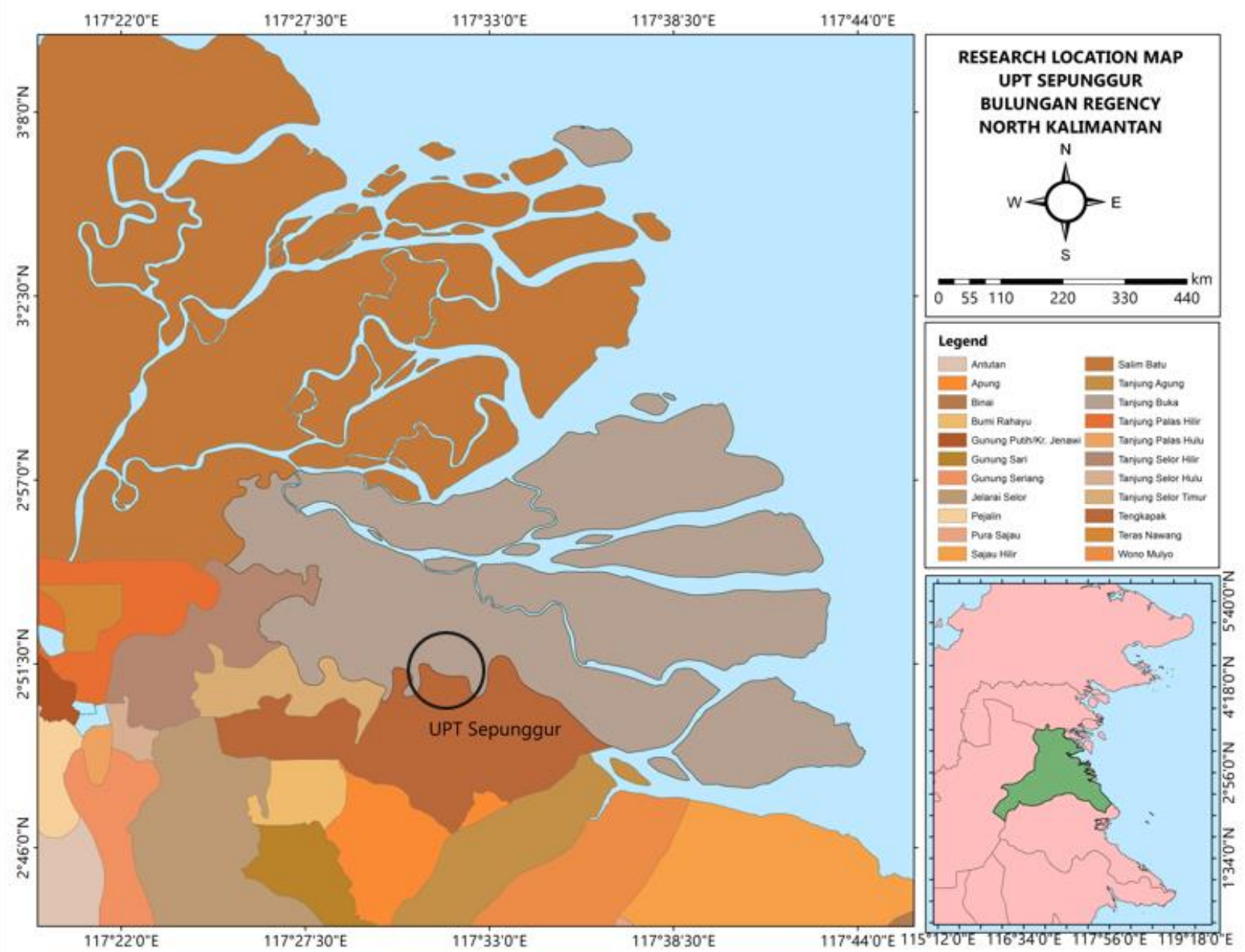

Figure 1. Research location at UPT Sepunggur, Bulungan District, North Kalimantan Province. 
The research required the following materials: (i) seeds of Inpara-1, Inpara-2, Inpara-3, Inpara-4, Inpara5 , and local variety; (ii) agricultural limestone (dolomite); (iii) Urea fertilizer; (iv) NPK fertilizer; and (v) pesticides (insecticides and fungicides). Meanwhile, a set of planting tools was used for soil processing.

This research applied the randomized Block Design (RBD) method by employing the new rice superior variety (NSV) factor. The rice variety were Inpara-1 (V1), Inpara-2 (V2), Inpara-3 (V3), Inpara-4 (V4), Inpara-5 (V5) and local variety (V6). Each treatment of variety was replicated three times. Each variety is tested in a $500 \mathrm{~m}^{2}$ plot area, so it occupied $3,000 \mathrm{~m}^{2}$ land for one iteration. The paddy was planted using jajar legowo 2:1 system, with planting distance $(50 \times 25) \times 12.5 \mathrm{~cm}$. The ameliorants applied to the field were dolomite at dosage $1,000 \mathrm{~kg} \mathrm{ha}^{-1}$.

There were three types of fertilizer, namely Urea, $\mathrm{NPK}$, and $\mathrm{KCl}$, which were applied three times during the paddy cycle. The basic fertilizer was given when field preparation using the dosage Urea of $50 \mathrm{~kg} \mathrm{ha}^{-1}$, NPK fertilizer $200 \mathrm{~kg} \mathrm{ha}^{-1}$, and $\mathrm{KCl} 50 \mathrm{~kg} \mathrm{ha}^{-1}$. The first additional fertilizer was applied when the plant was aged 25 days after planting (DAP), with dosage following the Leaf Colour Chart tool (LCC) or about 75$100 \mathrm{~kg}$ Urea ha-1. Meanwhile, the second additional fertilizer was applied at 40 DAP, with Urea $50 \mathrm{~kg} \mathrm{ha}^{-1}$ and NPK $50 \mathrm{~kg} \mathrm{ha}^{-1}$.

We observed several parameters namely plant growth analysis, harvest age, the number of filled grains, empty grain per panicle, the weight of 1,000 grains, and productivity. Analysis of growth data, yield components, and productivity was performed using the Analysis of Variant (ANOVA), and the data was further tested with the Duncan Multiple Range Test (DMRT) (Gomez and Wiley, 1994).

The income $(I)$ analysis was processed by the nominal approach, which was calculated as the difference between total revenue $(T R)$ and total cost (TC) (Equation 1-3).

$$
\begin{aligned}
& I=T R-T C \\
& T R=P_{y} \times Y \\
& T C=F C+V C
\end{aligned}
$$

where $P_{y}$ is rice price (IDR $\mathrm{kg}^{-1}$ ), and $Y$ rice production (kg). $F C$ is an acronym for fixed costs, which means the independent variable, recurring expenses to fulfill the basic needs of the rice production, while $V C$ stands for variable costs, which are influenced by the quantity changes of rice production.

Benefit-Cost Ratio (BCR) analysis was carried out to determine whether rice farming is feasible to be implemented in the study location. Production costs for each variety were assumed to be equal, according to price standards or costs at the time of research. If the value of $B C R<1$, the farming is not feasible. In contrast, if the value of $B C R \geq 1$, farming is feasible (Resiani and Sunanjaya, 2020).

\section{RESULTS AND DISCUSSIONS}

\section{Characteristics of Research Areas}

In general, tidal swamp can be categorized into types A, B, C, or D based on its overflow type. Swamp type $A$ is always inundated with high tides, both in the rainy and dry seasons. Swamp type $B$ is only covered by high tide in the rainy season, swamp type $C$ is not covered by the high tide but is influenced by the groundwater level with above $50 \mathrm{~cm}$ depth. Swamp type $D$ is similar to type $C$, but the groundwater levels below $50 \mathrm{~cm}$. This research was conducted in newly opened rice fields on tidal swamp types A and B. In the previous year, rice productivity in the region was low, which was below 2 tons $\mathrm{ha}^{-1}$ with planting time once a year.

UPT Sepunggur, Tanjung Palas Subdistrict is a granary in Bulungan District, especially for rice cultivation. Rainfed rice fields and tidal swamp area in Tanjung Palas Subdistrict (including in UPT Sepunggur) is highly potent with an area of about $10,000 \mathrm{ha}$, and a functional land area of 2,428 ha. Climate in Bulungan District is ever wet tropics, with temperatures ranges from $22-33^{\circ} \mathrm{C}$. Monthly rainfall is very high, which above $100 \mathrm{~mm}$ relatively low rainfall occurs in May-July. Figure 2 presents rainfall in 2018 compared to 20142017.

The research was conducted during the planting season of October 2018 until March 2019, as it was wet season and sufficiently provided water for rice plant development. During the experiment period, the monthly rainfall ranged from $105 \mathrm{~mm}-386 \mathrm{~mm}$. The three highest rainfall were in December at $386 \mathrm{~mm}$, following October $(277 \mathrm{~mm})$ and March $(222 \mathrm{~mm})$. The relatively low rainfall, was recorded in February (105 $\mathrm{mm})$, and November (127 mm).

The results of soil properties analysis (Table 2) showed that the content of clay fractions of newly opened rice fields in UPT Sepunggur was quite high around $42 \%$. This high proportion was caused by the formation of soil parent material in the sedimentation environment. Furthermore, the soil chemical properties are correlated between one element and another: $\mathrm{P}$ retention positively correlated with $\mathrm{Al}$ from amorphous materials, CEC positively correlated with organic carbon and $\mathrm{Al}-\mathrm{dd}$ negatively correlated with $\mathrm{pH}\left(\mathrm{H}_{2} \mathrm{O}\right)$ or soil acidity. Newly opened rice fields on Bulungan tidal swamp showed that $\mathrm{Mg}$ cation dominated the soil cation composition since it was influenced by the $\mathrm{MgCl}$ salts from the seawater. 


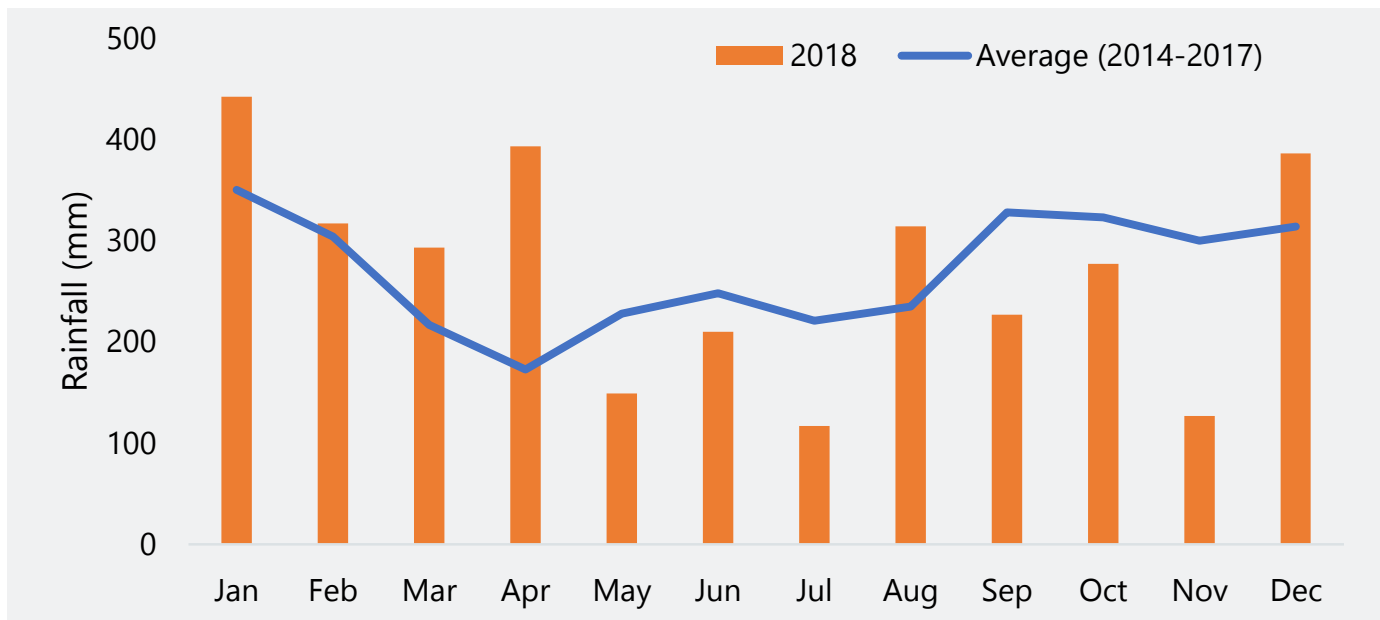

Figure 2. Monthly rainfall comparison of the 2014-2017 average and 2018 period (source: BPS, 2019).

Soil from newly opened rice fields on swamps contains smectite minerals which affect the physical and chemical properties of the soil. When rice fields containing sulfidic materials (pyrite minerals) were oxidized, the soil $\mathrm{pH}$ becomes very low and acid (Abdul Halim et al., 2018), hence it will disrupt the stability of smectite minerals. The smectite will be weathered and further resulting in Al being released from its crystal structure causing the environment to become saturated with Al (Fomina and Skorochod, 2020). This condition will affect rice plant growth and productivity. Newly opened rice fields on tidal swamp have several biophysical and chemical problems, such as: (1) water puddling at high and low tide, (2) high soil acidity due to the high solubility of aluminum $\left(\mathrm{Al}^{3+}\right)$, ferri $\left(\mathrm{Fe}^{3+}\right)$, and sulfate $\left(\mathrm{SO}_{4}{ }^{2-}\right)$, (3) low to medium soil fertility, and (4) ferro toxicity caused by a high concentration of dissolved iron in the soil (200-500 ppm). In newly opened rice fields, ferro toxicity often occurred and leading to a decrease in rice productivity for $30-100 \%$.

Table 2. The physical and chemical properties of the newly opened rice fields in UPT Sepunggur, Bulungan District.

\begin{tabular}{|c|c|c|c|c|}
\hline No & Description & Value & Unit & Criteria \\
\hline \multirow[t]{2}{*}{1.} & $\mathrm{pH} \mathrm{H} \mathrm{H}_{2} \mathrm{O}$ & $4.19-4.61$ & - & acid \\
\hline & $\mathrm{pH} \mathrm{KCl}$ & $3.28-3.65$ & - & neutral \\
\hline 2. & Water content & $38.61-46.88$ & $\%$ & \\
\hline 3. & C-Organic & $10.88-20.88$ & $\%$ & high \\
\hline 4. & N-Total & $0.69-0.91$ & $\%$ & moderate-high \\
\hline 5. & $\mathrm{P}_{2} \mathrm{O}_{5}$ available & 29.62 & Ppm & moderate \\
\hline 6. & $\mathrm{P}_{2} \mathrm{O}_{5}$ potential & $18.93-65.28$ & $\mathrm{me} / 100$ & moderate \\
\hline 7. & $\mathrm{~K}_{2} \mathrm{O}$ potential & $0.65-2.46$ & $\mathrm{mg} / 100$ & high \\
\hline 8. & CEC & $25.17-41.16$ & $\mathrm{cmol}(+) \mathrm{kg}^{-1}$ & moderate \\
\hline \multirow[t]{5}{*}{9} & Cation & & & \\
\hline & - Ca & $3.26-13.90$ & $\mathrm{me} / 100$ & low \\
\hline & $-M g$ & $6.06-13.55$ & $\mathrm{me} / 100$ & high \\
\hline & $-\mathrm{K}$ & $0.72-0.92$ & $\mathrm{me} / 100$ & high \\
\hline & $-\mathrm{Na}$ & $1.70-5.29$ & $\mathrm{me} / 100$ & moderate \\
\hline \multirow[t]{3}{*}{10.} & Cation & & & \\
\hline & - Exchange-Al ${ }^{3+}$ & $0.00-4.24$ & $\mathrm{me} / 100$ & low-high \\
\hline & - Exchange- $\mathrm{H}^{+}$ & $0.00-1.63$ & $\mathrm{me} / 100$ & low \\
\hline \multirow[t]{4}{*}{11.} & Texture & & & \\
\hline & - Sand & 4.4 & $\%$ & \\
\hline & - Silt & 54 & $\%$ & \\
\hline & - Clay & 42 & $\%$ & \\
\hline \multirow[t]{3}{*}{12.} & Heavy metal & & & \\
\hline & $-A g$ & 0.00 & ppm & \\
\hline & $-\mathrm{Cd}$ & 0.00 & ppm & \\
\hline \multirow[t]{3}{*}{13.} & Micronutrient & & & \\
\hline & - $\mathrm{Cu}$ & 0.00 & ppm & \\
\hline & $-\mathrm{Fe}$ & $10,190-10,564$ & ppm & high \\
\hline
\end{tabular}


High concentration of $\mathrm{Fe}^{2+}$, which caused ferro toxicity is due to redox reaction (Faria et al., 2021). The redox reaction is raised by poor drainage, deficiency of $\mathrm{K}, \mathrm{Ca}$, $\mathrm{Mg}, \mathrm{P}, \mathrm{Zn}$, and $\mathrm{Mn}$, as well as a low amount of soil oxygen. Newly opened rice fields that were infected by ferro toxicity can be recovered through proper water management, amelioration, fertilization, adjustment of planting time, and the use of tolerable crop varieties (Herviyanti et al., 2019).

\section{Superior Rice Varieties in Newly Opened Rice Fields: Growth and Yield Components}

The findings showed that growth diversed among rice varieties. Phenotypes and genotypes greatly influenced on the growth, plant height, the number of productive tillers, and the number of empty grains per panicle. Those characters were mainly controlled by genetic factors rather than environmental factors. The average plant height, number of productive tillers, and the harvesting age were presented in Table 3 , while the average percentage of empty grain per panicle, the weight of 1,000 grains, and productivity was in Table 4.

The plant height of the varieties ranged from 100.00-120.1 cm. The lowest plant height was Inpara-1 $(100 \mathrm{~cm})$, while the highest was local variety $(120.1 \mathrm{~cm})$. The differences in plant height between each rice variety depended on plant genetic factors and environmental factors. The highest number of productive tillers was Inpara-4 with 15.7 stems per clump. However, the result was not significantly different from the number of productive tillers in Inpara-3 and Inpara-5. Regardless, this result was significantly different from Inpara-1 and Inpara-2.

The lowest number of productive tillers per clump was the local variety with 11.1 stems per clump. This number was influenced by genetic and environmental factors, as well as fertilization factors. The fertilizer that affected the number of tillers was $\mathrm{N}$ (nitrogen). Nitrogen played an important role in rice growth (Jahan et al., 2020).
The average rice harvesting age ranged from 117-155 days after planting (DAP). Inpara-4 variety had the fastest harvesting age, which was only 117 DAP, whereas for local variety was the longest up to 155 DAP. The harvesting age of Inpara-1, Inpara-2, Inpara-3, Inpara-4, and Inpara-5 was not significantly different each other.

The percentage of empty grain from the tested rice varieties varied between $24.00 \%$ and $27.15 \%$. Inpara-1 variety had the lowest average of empty grain, about $24 \%$, while the highest was the local variety at $27.15 \%$. This percentage would affect the rice productivity and was influenced by not only genetics and environmental factors but also pest attacks or disease.

The weight of 1,000 grains of Inpara variety ranged from 18.10-23.50 g. Inpara-1 variety weighted the highest around $23.50 \mathrm{~g}$, and the local variety was the lowest about $18.10 \mathrm{~g}$. The weight of 1,000 grains was a component that also influenced rice productivity.

The results corresponded with the study conducted in Merauke (Djufry and Kasim, 2015), which revealed that the weight of 1,000 grains and rice productivity for Inpara-1 variety was the highest compared to other varieties. Rice plants in the tidal swamp were poisoned by high levels of $\mathrm{Fe} 2+$ in the soil.

Ferro toxicity would affect the growing plant. High levels of iron in the soil would increasingly inhibit the growth of rice plants. Inpara- 1 reported being tolerant of ferro toxicity in new rice fields especially for tidal swamp (Kalbuadi et al., 2020).

\section{Rice Productivity Analysis}

The rice productivity ranged from 2.60 to 5.75 tons $\mathrm{ha}^{-1}$. The highest rice productivity was Inpara-1 variety $(5.75$ tonnes ha-1), while the local variety was the lowest $\left(2.6\right.$ tons $\left.\mathrm{ha}^{-1}\right)$. This productivity variation was similar to previous research which reported that the productivity of rice on swamp differs among its varieties (Koesrini et al., 2019). According to the description of the variety shown in Table 5, it can be fi-

Table 3. The average plant height, number of productive tillers, and harvesting age.

\begin{tabular}{ccccc}
\hline No & Varieties & Plant height (cm) & $\begin{array}{c}\text { Productive tiller } \\
\text { (seeds per clump) }\end{array}$ & $\begin{array}{c}\text { Harvesting age } \\
\text { (day) }\end{array}$ \\
\hline 1 & V1 (Inpara-1) & $100.00^{\mathrm{c}}$ & $12.30^{\mathrm{b}}$ & $118^{\mathrm{b}}$ \\
2 & V2 (Inpara-2) & $105.30^{\mathrm{b}}$ & $12.50^{\mathrm{b}}$ & $119^{\mathrm{b}}$ \\
3 & V3 (Inpara-3) & $101.00^{\mathrm{c}}$ & $15.20^{\mathrm{a}}$ & $118^{\mathrm{b}}$ \\
4 & V4 (Inpara-4) & $102.60^{\mathrm{c}}$ & $15.70^{\mathrm{a}}$ & $117^{\mathrm{b}}$ \\
5 & V5 (Inpara-5) & $104.15^{\mathrm{b}}$ & $15.30^{\mathrm{a}}$ & $120^{\mathrm{b}}$ \\
6 & V6 (Local) & $120,10^{\mathrm{a}}$ & $11,10^{\mathrm{c}}$ & $155^{\mathrm{a}}$ \\
\hline & CV & $2,40 \%$ & $5,47 \%$ & $3,63 \%$ \\
\hline
\end{tabular}

Note: the same letter indexed on the values in one column means not significantly different $(p<0.05)$ 
Table 4. The average percentage of empty grain per panicle, the weight of 1,000 grains, and productivity.

\begin{tabular}{ccccc}
\hline No & Varieties & $\begin{array}{c}\text { Empty grain percentage } \\
\mathbf{( \% )}\end{array}$ & $\begin{array}{c}\text { Weight of 1,000 grains } \\
\mathbf{( g )}\end{array}$ & $\begin{array}{c}\text { Productivity } \\
\text { (ton ha }\end{array}$ \\
\hline 1 & V1 (Inpara-1) & $24.00^{\mathrm{b}}$ & $23.50^{\mathrm{a}}$ & $5.75^{\mathrm{a}}$ \\
2 & V2 (Inpara-2) & $25.15^{\mathrm{a}}$ & $21.80^{\mathrm{b}}$ & $4.75^{\mathrm{b}}$ \\
3 & V3 (Inpara-3) & $26.00^{\mathrm{a}}$ & $20.50^{\mathrm{b}}$ & $4.10^{\mathrm{bc}}$ \\
4 & V4 (Inpara-4) & $26.10^{\mathrm{a}}$ & $20.10^{\mathrm{b}}$ & $4.00^{\mathrm{c}}$ \\
5 & V5 (Inpara-5) & $24.60^{\mathrm{b}}$ & $19.50^{\mathrm{b}}$ & $3.88^{\mathrm{c}}$ \\
6 & V6 (Local) & $27.15^{\mathrm{a}}$ & $18.10^{\mathrm{c}}$ & $2.60^{\mathrm{d}}$ \\
\hline & CV & $3,28 \%$ & $6,00 \%$ & $5,19 \%$ \\
\hline
\end{tabular}

Note: Values followed by the same letter in each column are not significantly different $(p<0.05)$

gured out that rice productivity in newly opened rice fields was generally below the potential yield (Djufry and Kasim, 2015). Rice productivity was influenced by the interaction between genetics and environmental factors. Environmental factors that affect the productivity of newly opened rice fields were poor land management, inefficient water system, and low soil fertility rate (Liliane and Charles, 2020).

Most of the rice superior varieties for swamp (Inpara) produced by the Agricultural Research and Development Agency from the Ministry of Agriculture are tolerant of ferro toxicity. Based on the description, tolerable ferro toxicity rice varieties were Inpara-1, Inpara-2, Inpara-3, Inpara-6, Inpara-7, Inpara-8, Inpara9, and Inpara-10 (Balitbangtan, 2019). Previous research showed that each of these varieties had a different ability in absorbing nutrients and various levels of tolerance to ferro toxicity. Inpara- 1 variety was the most tolerant, while Inpara-5 was intolerant towards ferro toxicity. Ferro toxicity in the swamp could lead to a decrease in rice productivity (Sikirou et al., 2016). Therefore, the farmer should consider the tolerable ferro toxicity when selecting varieties to be cultivated in tidal swamp.
Research by Koesrini et al. (2019) in the border region of West Kalimantan showed that Inpara-1 productivity was the highest among other varieties. Rice productivity on swamp in the research area reached 6.6 tons ha ${ }^{-1}$. On the other hand, the results of research on swamp in Merauke (Handayani et al., 2016) indicated that Inpara-5 productivity was 3.30 tons ha- ${ }^{-1}$, and became the lowest compared to others.

The rice productivity from the results of the research on newly opened paddy fields at UPT Sepunggur was also the same as rice productivity at research locations in other provinces. Rice productivity in newly opened paddy fields was below the potential yield, due to relatively low soil fertility and not optimal water management.

\section{Analysis of farming systems}

The analysis of rice farming on newly opened rice fields in the tidal swamp in UPT Sepunggur, Bulungan District showed that new superior varieties had a $B C R>1$, while local rice varieties had a $B C R<1$ (Table 6). Compared to the variety description (Table 5 ), the rice productivity yielded in UPT Sepunggur was below its potential. The lower productivity was due to several land conditions that had not been managed properly,

Table 5. Description of Inbrida Padi Rawa (Inpara) variety (source: Balitbangtan, 2019).

\begin{tabular}{lcccl}
\hline \multirow{2}{*}{ Name of variety } & $\begin{array}{c}\text { Age } \\
\text { (days) }\end{array}$ & $\begin{array}{c}\text { Productivity } \\
\text { (tons ha-1) }\end{array}$ & Abiotic & Tolerance to insecurity \\
\cline { 4 - 5 } Inpara 1 & 131 & 6.5 & Fe and Al & Planthopper, bacterial leaf blight, blast \\
\hline Inpara 2 & 128 & 6.1 & Fe and Al & Planthopper, bacterial leaf blight, blast \\
\hline Inpara 3 & 127 & 5.6 & Fe, Al submerged & Planthopper, blast \\
\hline Inpara 4 & 135 & 7.6 & Submerged & Planthopper, bacterial leafblight \\
\hline Inpara 5 & 115 & 7.2 & Submerged & Bacterial leaf blight \\
\hline Inpara 6 & 117 & 6.0 & Fe & Blast and bacterial leaf blight \\
\hline Inpara 7 & 114 & 5.1 & Fe, Al & Tungro, blast \\
\hline Inpara 8 Agritan & 115 & 6.0 & Fe & Bacterial leaf blight, blast \\
\hline Inpara 9 Agritan & 107 & 5.6 & Fe & Bacterial leaf blight, tungro \\
\hline Inpara 10 BLB & 126 & 6.8 & Fe & Bacterial leaf blight, blast \\
\hline
\end{tabular}


Table 6. Analysis of rice farming on a newly opened rice field in UPT Sepunggur, Bulungan District.

\begin{tabular}{lccccccc}
\hline \multirow{2}{*}{ Parameters } & \multirow{2}{*}{ Units } & \multicolumn{5}{c}{ Rice Varieties } \\
\cline { 3 - 8 } & & $\begin{array}{c}\text { V1 } \\
\text { Inpara-1 }\end{array}$ & $\begin{array}{c}\text { V2 } \\
\text { Inpara-2 }\end{array}$ & $\begin{array}{c}\text { V3 } \\
\text { Inpara-3 }\end{array}$ & $\begin{array}{c}\text { V4 } \\
\text { Inpara-4 }\end{array}$ & $\begin{array}{c}\text { V5 } \\
\text { Inpara-5 }\end{array}$ & $\begin{array}{c}\text { V6 } \\
\text { Local Var }\end{array}$ \\
\hline Productivity & t ha $^{-1}$ GKP & 5,750 & 4,750 & 4,100 & 4,000 & 3,900 & 2,600 \\
\hline Production costs & in IDR 1,000 & 7,750 & 7,750 & 7,750 & 7,750 & 7,750 & 7,750 \\
\hline Acceptance & in IDR 1,000 & 23,000 & 19,000 & 16,400 & 16,000 & 15,600 & 10,400 \\
\hline Income* & in IDR 1,000 & 15,250 & 11,250 & 8,650 & 8,250 & 7,850 & 2,650 \\
\hline BCR & - & 1.97 & 1.45 & 1.12 & 1.06 & 1.01 & 0.34 \\
\hline
\end{tabular}

*note: the price of Dry Grain Harvest Price (GKP) $=$ IDR 4,000 kg-1

such as the relatively low level of soil fertility, and the quite high presence of pests and diseases. However, the rice productivity was higher compared to the productivity of the local variety which was only 2.6 tons $\mathrm{ha}^{-1}$.

The highest $B C R$ value was attained by Inpara-1 variety, and the value was correlated with the productivity of each rice variety. Based on the productivity of each rice variety, Inpara-1 had the highest $B C R$ value at 1.97 since it had the highest productivity. The results of other studies revealed that productivity and $B C R$ among rice varieties tested were different following research locations (Handayani et al., 2016). The result conducted by Rina and Koesrini (2018) in the border region of West Kalimantan also explained that Inpara rice varieties made a higher profit compared to local rice varieties. Rice variety Inpara- 1 had potential yield of 6.6 tons $\mathrm{ha}^{-1}$, adaptive in the tidal swamp, resistant to $\mathrm{Fe}$ and $\mathrm{Al}$ stresses, and tolerant to planthopper, bacterial leaf blight, as well as blast.

\section{CONCLUSIONS}

Tidal swamp in UPT Sepunggur, Bulungan District had been utilized for rice cultivation. An optimization effort to increase rice productivity was by introducing adaptive new superior varieties (NSV). The productivity of NSV ranged from 2.60-5.75 tons ha-1. The highest rice productivity was Inpara- 1 with a $B C R$ value higher than 1 . Meanwhile, the local variety had the lowest productivity as the BCR value was far less than 1 . The results showed that two most adaptive rice varieties, which were Inpara-1 and Inpara-2, had a relatively high $B C R$ value and were feasible to be cultivated. Regardless, this research was only conducted in one growing season, so further research in other regions and different growing seasons is necessary.

\section{ACKNOWLEDGEMENT}

The research was funded by the Assessment Institute for Agricultural Technology (AIAT) of East Kalimantan-Indonesian, Agency for Agricultural
Research and Development. The authors thank to two anonymous reviewers for their valuable comments on the manuscript.

\section{REFERENCES}

Abdul Halim, N.S., Abdullah, R., Karsani, S.A., Osman, N., Panhwar, Q.A., Ishak, C.F., 2018. Influence of Soil Amendments on the Growth and Yield of Rice in Acidic Soil. Agronomy 8, 165. https://doi.org/10.3390/agronomy8090165

Alberto, A., Dasanto, B.D., 2010. Model Perubahan Penggunaan Lahan dan Pendugaan Cadangan Karbon di Daerah Aliran Sungai Cisadane, Jawa Barat. Agromet 24. https://doi.org/10.29244/ j.agromet.24.2.18-26

Alfayanti, A., Mikasari, W., Rahman, T., 2020. Feasibility of Swamp Paddy Farming with New Superior Varieties and Different Planting System. Journal of Suboptimal Lands 9, 50-56. https://doi.org/ 10.33230/jlso.9.1.2020.467

Aristya, V.E., Trisyono, Y.A., Mulyo, J.H., Taryono, T., 2021. Participatory Varietal Selection for Promising Rice Lines. Sustainability 13, 6856. https://doi.org/10.3390/su13126856

Balitbangtan, 2019. Deskripsi Varietas Unggul Baru Padi. Badan Litbang Pertanian, Jakarta.

BPS, 2019. Kabupaten Bulungan Dalam Angka 2019. Badan Pusat Statistik.

Dawid, J., Hailu, G., 2017. Application of Lime for Acid Soil Amelioration and Better Soybean Performance in SouthWestern Ethiopia. Journal of Biology, Agriculture and Healthcare 7, 95100.

Djufry, F., Kasim, A., 2015. Adaptability Test on New High Yielding Varieties of Swamp Rice Planted on Newly Opened Paddy Field in The District of Merauke Province of Papua. J. Agrotan 1, 99109.

Faria, J.M.S., Teixeira, D.M., Pinto, A.P., Brito, I., Barrulas, P., Carvalho, M., 2021. Aluminium, Iron and Silicon Subcellular Redistribution in Wheat 
Induced by Manganese Toxicity. Applied Sciences 11, 8745. https://doi.org/10.3390/ app 11188745

Fomina, M., Skorochod, I., 2020. Microbial Interaction with Clay Minerals and Its Environmental and Biotechnological Implications. Minerals 10, 861. https://doi.org/10.3390/min10100861

Gatzweiler, F.W., Von Braun, J., 2016. Technological and institutional innovations for marginalized smallholders in agricultural development. Springer Nature, Switzerland.

Gomez, A.A., Wiley, J., 1994. Statistical Procedures For Agricultural Research, 2nd ed. John Wilet \& Sons.

Gusmiatun, N.M., 2020. Optimization of Rice Plant Production (Oryza Sativa L.) in Swamp Land through Integrated Plant Management. International Journal of Advanced Science and Technology 29, 5241-5253.

Handayani, R., Lestari, S., Kaim, A., 2016. Pengkajian Varietas Padi Unggul Baru Pada Lahan Rawa Pasang Surut $\mathrm{Di}$ Kabupaten Merauke. Informatika Pertanian 23, 59. https://doi.org/10. 21082/ip.v23n1.2014.p59-64

Herviyanti, Prasetyo, T.B., Ahmad, F., Saidi, A., 2019. Humic Acid and Water Management to Decrease Ferro $(\mathrm{Fe} 2+)$ Solution and Increase Productivity of Established New Rice Field. Journal of Tropical Soils 17, 9-17. https://doi.org/10.5400/jts.2012.v17i1.9-17

Jahan, A., Islam, A., Sarkar, Md.I.U., Iqbal, M., Ahmed, Md.N., Islam, Md.R., 2020. Nitrogen response of two high yielding rice varieties as influenced by nitrogen levels and growing seasons. Geology, Ecology, and Landscapes 00, 1-8. https://doi.org/10.1080/24749508.2020.17425 09

Kalbuadi, D.N., Santi, L.P., Goenadi, D.H., Barus, J., 2020. Application of bio-silicic acid to improve yield and fertilizer efficiency of paddy on tidal swamp land. E-Journal Menara Perkebunan 88. https://doi.org/10.22302/iribb.jur.mp.v88i2.37 8

Koesrini, K., Alwi, M., Saleh, M., 2019. Yield Performance of High Yielding Rice Varieties in Two Different Planting Seasons in Swamp Land West Kalimantan Border Area. Jurnal Penelitian Pertanian Tanaman Pangan 3, 53. https://doi.org/10.21082/jpptp.v3n2.2019.p53 $-59$

Lanya, I., Dibia, I.N., Diara, I.W., Suarjaya, D.G., 2017. Analysis of Subak Landuse Change Due to Tourism Accomodation Development in North Kuta Sub-district, Badung Regency, Indonesia.
IOP Conference Series: Earth and Environmental Science 98, 012024. https://doi. org/10.1088/1755-1315/98/1/012024

Liliane, T.N., Charles, M.S., 2020. Factors Affecting Yield of Crops. Agronomy-Climate Change \& Food Security 9. https://doi.org/10.5772/intechopen. 90672

Maruapey, A., Wicaksana, N., Karuniawan, A., Windarsih, G., Utami, D.W., 2020. Swampy rice lines for iron toxicity tolerance and yield components performance under inland swamp at Sorong, West Papua, Indonesia. Biodiversitas Journal of Biological Diversity 21. https://doi.org/10. 13057/biodiv/d211146

Mugo, J.N., Karanja, N.N., Gachene, C.K., Dittert, K., Nyawade, S.O., Schulte-Geldermann, E., 2020. Assessment of soil fertility and potato crop nutrient status in central and eastern highlands of Kenya. Sci Rep 10, 7779. https://doi.org/ 10.1038/s41598-020-64036-x

Mulyani, A., Kuncoro, D., Nursyamsi, D., Agus, F., 2016. Analysis of Paddy Field Conversion: The Utilization of High Resolution Spatial Data Shows an Alarming Conversion Rate. Jurnal Tanah dan Iklim 40, 121-133.

Paiman, Ardiyanta, Ansar, M., Effendy, I., Sumbodo, B.T., 2020. Rice Cultivation of Superior Variety in Swamps to Increase Food Security in Indonesia. Reviews in Agricultural Science 8, 300-309. https://doi.org/10.7831/ras.8.0_300

Pravitasari, A.E., Suhada, A., Mulya, S.P., Rustiadi, E., Murtadho, A., Wulandari, S., Widodo, C.E., 2019. Land use/cover changes and spatial distribution pattern of rice field decreasing trend in Serang Regency, Banten Province. IOP Conference Series: Earth and Environmental Science 399, 012033. https://doi.org/10.1088/ 1755-1315/399/1/012033

Resiani, N.M.D., Sunanjaya, I.W., 2020. The Efficiency of Water in Supporting Local Wisdom and Food Sustainability in Subak Sange, Bali Indonesia. Agromet 34, 67-74. https://doi.org/10.29244/j. agromet.34.2.67-74

Rina, Y., Koesrini, 2018. Adoption of Inpara and Margasari Varieties in Tidal Swamp Lands. Jurnal Pertanian Agros 18, 65-80.

Rumanti, I.A., Hairmansis, A., Nugraha, Y., Nafisah, Susanto, U., Wardana, P., Subandiono, R.E., Zaini, Z., Sembiring, H., Khan, N.I., Singh, R.K., Johnson, D.E., Stuart, A.M., Kato, Y., 2018. Development of tolerant rice varieties for stress-prone ecosystems in the coastal deltas of Indonesia. Field Crops Research 223, 75-82. https://doi.org/10.1016/j.fcr.2018.04.006 
Sikirou, M., Saito, K., Dramé, K.N., Saidou, A., Dieng, I., Ahanchédé, A., Venuprasad, R., 2016. Soilbased screening for iron toxicity tolerance in rice using pots. Plant Production Science 19, 489-496. https://doi.org/10.1080/1343943X. 2016.1186496

Suciantini, Estiningtyas, W., Rahman, A., 2020. Determinant Factor of Food Farming Vulnerability in Banten Province To Support Climate Change Adaptation. Agromet 34, 129 142. https://doi.org/10.29244/j.agromet.34.2. 129-142

Suciantini, S., Impron, I., Boer, R., 2008. Penilaian Risiko Iklim pada Sistem Pertanian Ekosistem Lahan Rawa Pasang Surut (Studi Kasus di Delta Telang I, Delta Telang II dan Delta Air Saleh, Banyuasin, Sumatera Selatan). Agromet 22, 244628. https://doi.org/10.29244/j.agromet.22.2.118131

Sugiarto, Y., Estiningtyas, W., Dewi, W.S., 2017. Analysis of Climate Index with Historical Burn Analysis Method for Climate Change Adaptation (A Case Study in Pacitan District, East Java). Agromet 31, 1-10. https://doi.org/10.29244/ j.agromet.31.1.1-10
Surahman, A., Soni, P., Shivakoti, G.P., 2018. Are peatland farming systems sustainable? Case study on assessing existing farming systems in the peatland of Central Kalimantan, Indonesia. Journal of Integrative Environmental Sciences 15, 1-19. https://doi.org/10.1080/1943815X. 2017.1412326

Weissman, D.S., Tully, K.L., 2020. Saltwater intrusion affects nutrient concentrations in soil porewater and surface waters of coastal habitats. Ecosphere 11. https://doi.org/10. 1002/ecs2.3041

Widiatmaka, Ambarwulan, W., Setiawan, Y., Walter, C., 2016. Assessing the Suitability and Availability of Land for Agriculture in Tuban Regency, East Java, Indonesia. Applied and Environmental Soil Science 2016, e7302148. https://doi.org/ 10.1155/2016/7302148

Wijaya, S., 2019. Indonesian food culture mapping: a starter contribution to promote Indonesian culinary tourism. Journal of Ethnic Foods 6, 9. https://doi.org/10.1186/s42779-019-0009-3 